\title{
Confirmation of Antimicrobial Resistance by Using Resistance Genes of Isolated Salmonella spp. in Chicken Houses of North West, South Africa
}

\author{
Tsepo Ramatla $^{1}$, Moeti O. Taioe ${ }^{2}$, Oriel M.M Thekisoe ${ }^{3}$ and Michelo Syakalima ${ }^{1}$ \\ ${ }^{1}$ Department of Animal Health, School of Agriculture, North-West University, Private Bag X2046, Mmabatho, 2735, South Africa \\ ${ }^{2}$ National Zoological Garden, South African National Biodiversity Institute, PO Box 754, Pretoria, 0001, South Africa \\ ${ }^{3}$ Unit for Environmental Sciences and Management, North-West University, Private Bag X6001, Potchefstroom 2520, South Africa \\ *Corresponding author's Email: ra21205450@gmail.com; ORCID: 0000-0002-0473-8075
}

\begin{abstract}
The widespread use of antibiotics for treatment of bacterial infections and growth promotion in the poultry industry has effectively increased antibiotic resistance around the world. Antibiotics resistance can be caused by different mechanisms and can be determined through phenotypic and molecular methods. The aim of the present study was to determine the occurrence of antibiotic resistance in Salmonella serovars isolated from layer chickens and rats in poultry houses. Phenotypic testing of antimicrobial resistance was performed using the Kirby-Bauer disc diffusion method. Furthermore, molecular evaluations and PCR assay were conducted for detecting resistance genes and class 1 integrons. A total of 144 Salmonella isolates (68 from rats and 46 from chickens) serovars were assessed. Evaluation of phenotypic resistance patterns demonstrated that Salmonella isolates have the highest antibiotic resistance for rifampicin (100\%) followed by tetracycline (68\%), ciprofloxacin (48\%), sulphonamides $(42 \%)$, chloramphenicol (39\%), nalidixic acid (33\%), ampicillin (28\%), cephalothin (18\%), streptomycin (18\%), amoxicillin-clavulanic acid (6\%), enrofloxacin (5\%), and gentamicin (4\%). Some Salmonella serovars revealed multi-drug resistance for up to four different antibiotics. According to PCR results, all the tested resistant gene markers (tet, cat, blaTEM, sul, qnrA, and aadA) were detected from the Salmonella isolates. The study further confirmed that $68 \%$ of Salmonella isolates were harboring class 1 integrons and the majority of the isolates $(n=52)$ which were harboring these genes were recovered from the rats. The results of the present study provided that the Salmonella spp. isolated from chickens and rats in poultry houses, exhibited significant antibiotic resistance. Moreover, the current research ultimately highlights the importance of rats as carriers of antibiotic-resistant bacteria and the risk of transmission to chickens and humans.
\end{abstract}

Key words: Antibiotic resistance pattern, Class 1 integrons, Resistance genes, Salmonella serovars

\section{INTRODUCTION}

Several antimicrobial agents are used in animals and humans to treat certain infections (Raissy and Ansari, 2011). Despite the obvious benefits, improper use of antibiotics can lead to the development of bacterial resistance in infectious diseases (Hong et al., 2018). Approximately 95\% of antibiotics administered to livestock are excreted unchanged, therefore, people who live in an environment close to animal waste are constantly exposed to antibiotics and this condition may develop resistance (Choi, 2007).

Antibiotic resistance can be conferred by intrinsic or acquired mechanisms (Schroeder et al., 2017). Mechanisms of acquired resistance can be through Horizontal Gene Transfer (HGT) or elevated mutation rates (Schroeder et al., 2017). In general, mechanisms of antibiotic resistance are classified into three categories including modification of cell permeability, replacement or modification of the antibiotic targets and inactivation of the antibiotics via enzymatic destruction or modification (Frye and Jackson, 2013; Schroeder et al., 2017).

Recent studies have demonstrated that Salmonella serotypes such as $S$. heidelberg, $S$. typhimurium, $S$. infantis, $S$. uganda, $S$. newport, $S$. typhi, $S$. paratyphi, $S$. agona and $S$. hadar exhibit antibiotic resistance (Mathole et al., 2017; Zhao et al., 2017; Odoch et al., 2018; Thung et al., 2018). Furthermore, the increasing frequency of resistance of Salmonella spp. to antibiotics such as chloramphenicol, tetracycline, and ampicillin has been reported in many countries (Olobatoke and Mulugeta, 2015; Odoch et al., 2018; Thung et al., 2018). Antimicrobial resistance, especially in Salmonella serovars, has also been implicated to play a role in their virulence (Mathole et al., 2017). 
It has now been established that Salmonella spp. contain different Antibiotic Resistance Genes (ARGs) (Abatcha et al., 2018). Most of the resistance genes are located on the plasmids, bacterial chromosome or transposons which can be transferred by mobile genetic elements. Apart from antibiotic resistance genes detected from Salmonella spp. and resistance integrons included class 1, 2 and 3 has also been identified from Salmonella spp. (Odoch et al., 2018). The majority of the ARGs have mostly located in class 1 integrons. So that, class 1 integron-mediated antimicrobial resistance among diverse Salmonella serovars (Thong and Modarressi, 2011).

Although rodents are not normally treated with antibiotics, they have still been found to harbor antibiotic-resistant bacteria in the environment. Therefore, rats can be used as good indicators for the presence of antibiotic-resistant bacteria in a specific area. Currently, there is still inadequate information about the antibiotic resistance patterns of Salmonella spp. in chicken and rats in South Africa. Therefore, the present study sought to document the occurrence of antibiotic-resistant Salmonella serovars in chickens and rats found in chicken houses of North West Province, South Africa.

\section{MATERIALS AND METHODS}

\section{Ethical Approval}

Prior to the commencement of the study, the research proposal was approved by the Animal Research Ethics Committee (Ref No: NWU-00274-18-A5) following guidelines of North West University Research Ethics Regulatory Committee (NWU-RERC), North West, South Africa.

\section{Sampling}

A list of layer farms in Mafikeng, North West province of South Africa were randomly selected by using the records of Agriculture Department. A few farms in the north, south, east, and west were randomly selected. A total of 274 fecal samples were collected from chicken $(n=120)$ and rats $(n=154)$ in six commercial farms. Cleaning and disinfection of surfaces before sampling of rats were done with $70 \%$ ethanol to avoid cross-contamination. Dissection of the abdominal cavity was done using a surgical blade, a pair of forceps and the samples were harvested from cecum. The fecal samples of chickens were collected from three different floors in each poultry farm once a week. This sampling was done to have a good representation and distribution of the organisms. The collected samples were packed in properly labelled sterile polyethylene bags and transported under a complete aseptic condition in an icebox, then processed immediately upon arrival to the laboratory. All samples were labelled and prepared for analysis however the samples which did not analysed within 24 hours, immediately refrigerated at $-4^{\circ} \mathrm{C}$.

\section{Bacteria isolates}

Salmonella was isolated from feces following the International Organization for Standardization method (ISO6579: 2002). The DNA of the isolates were amplified using Polymerase Chain Reaction (PCR) and then PCR products were sequenced. Generated sequences were aligned on the GenBank database using basic local alignment search tool from the National Center for Biotechnology Information to identify sequences with high similarity. The $16 S \mathrm{rDNA}$ gene sequences of Salmonella isolates in the current study were deposited into the GenBank database and were given accession numbers ranging from MH352147 to MH352214 for rat and from MH356670 to MH356715 for chicken.

\section{Phenotypic test for detecting antimicrobial resistance}

The phenotypic antibiotic resistance test was performed using the Kirby-Bauer disc diffusion method (Magiorakos et al., 2012). Pure Salmonella isolates were sub-cultured on nutrient agar (Merck, Wadeville, South Africa) medium, incubated at $37^{\circ} \mathrm{C}$ for up to $24 \mathrm{~h}$. Then fresh overnight cultures were used for antibiotic sensitivity tests. Aliquots of 100 $\mu \mathrm{l}$ from the suspensions were spread-plated on Mueller-Hinton agar (Biolab, supplied by Merck) using a sterile cotton swab. Single disc diffusion method was used to assess the susceptibility of Salmonella isolates to commonly used antimicrobial agents. A total of 12 antibiotic discs (Davies diagnostics, SA) were used in this investigation including gentamicin (GM; $10 \mu \mathrm{g}$ ), ciprofloxacin (CIP; $5 \mu \mathrm{g}$ ), rifampicin (RIF; $5 \mu \mathrm{g}$ ), chloramphenicol (C, $30 \mu \mathrm{g}$ ), nalidixic acid (NA; $30 \mu \mathrm{g}$ ), ampicillin (AMP; $10 \mu \mathrm{g}$ ), enrofloxacin (ENR; $5 \mu \mathrm{g}$ ), tetracycline (TE; $30 \mu \mathrm{g}$ ), cephalothin (KF,30 $\mu \mathrm{g}$ ), Sulphonamides (SSS; $300 \mu \mathrm{g}$ ), streptomycin (STR; $10 \mu \mathrm{g}$ ) and amoxicillin-clavulanic acid (AMC; $30 \mu \mathrm{g}$ ). The antimicrobial profile of isolated bacteria to different antibiotics was determined following recommendations of the clinical laboratory institute standards interpreted as intermediate (I), sensitive (S), and resistant (R). The E. coli (ATCC 25922) was used as quality control. Strains which showed resistance to at least three classes of antibiotics were considered as multi-drug-resistant (MDR) isolates (Zhao et al., 2017). 


\section{Genotypic test for detecting antimicrobial resistant}

A total of six antimicrobial resistance genes (blaTEM, tet, sul, cat, qnrA, and aadA) were amplified by PCR using respective primer sets targeting the different antimicrobial resistant genes including class 1 integrons. The details of oligonucleotide sequences, their base pairs (bp) including the PCR cycling conditions are shown in table 1. Resistance to aminoglycosides is associated with carriage of aadA gene; resistance to quinolones is associated with carriage of qnrA gene; resistance to $\beta$-lactams is associated with carriage of a blaTEM (ESBL) gene; resistance to chloramphenicol is associated with carriage of cat gene; resistance to sulfonamide is associated with carriage of sul genes, and resistance to tetracycline is associated with tet gene. In addition, intIl is associated with class 1 integrons (Ozgen, 2007; Olobatoke and Mulugeta, 2015; Kim et al., 2016).

Table 1. The list of different primers used to detect antimicrobial resistance in Salmonella species

\begin{tabular}{|c|c|c|c|c|}
\hline Primers & Sequence (5'-3') & $\begin{array}{l}\text { Amplicon } \\
\text { size (bp) }\end{array}$ & Conditions & References \\
\hline $\begin{array}{l}\text { Sul3 } \\
\text { Sul4 }\end{array}$ & $\begin{array}{l}\text { F: TCAACATAACCTCGGACAGT } \\
\text { R: GATGAAGTCAGCTCCACCT }\end{array}$ & 707 & $\begin{array}{l}94^{\circ} \mathrm{C}, 5 \mathrm{mins} ; 30 \mathrm{cyc} \text { of } 94^{\circ} \mathrm{C}, 30 \mathrm{~S} ; 60^{\circ} \mathrm{C} \\
\text { for } 40 \mathrm{~s}, 72^{\circ} \mathrm{C} \text { for } 30 \mathrm{~S} \text {, ext. at } 72^{\circ} \mathrm{C}, 5 \mathrm{mins}\end{array}$ & (Özgen, 2007) \\
\hline $\begin{array}{l}\text { tem1 } \\
\text { tem } 2\end{array}$ & $\begin{array}{l}\text { F ATGAGTATTCAACATTTCCGTG } \\
\text { R TTACCAATGCTTAATCAGTGAG }\end{array}$ & 792 & $\begin{array}{l}95^{\circ} \mathrm{C}, 3 \mathrm{~min} ; 30 \mathrm{cyc} \text { of } 95^{\circ} \mathrm{C}, 1 \mathrm{~min}, 55^{\circ} \mathrm{C} \text {, } \\
1 \mathrm{~min}, 72^{\circ} \mathrm{C}, 1 \mathrm{~min} \text {, ext. at } 72^{\circ} \mathrm{C}, 5 \mathrm{mins}\end{array}$ & $\begin{array}{l}\text { (Olobatoke and Mulugeta, } \\
\text { 2015), }\end{array}$ \\
\hline $\begin{array}{l}\text { tet } \\
\text { tet }\end{array}$ & $\begin{array}{l}\text { F: GCACTTGTCTCCTGTTTACTCCCC } \\
\text { R: CCTTGTGGTTATGTTTTGGTTCCG }\end{array}$ & 659 & $\begin{array}{l}94^{\circ} \mathrm{C}, 2 \mathrm{mins} ; 35 \text { cyc. of } 94^{\circ} \mathrm{C}, 20 \mathrm{~S}, 53^{\circ} \mathrm{C} \text {, } \\
10 \mathrm{~S}, 65^{\circ} \mathrm{C}, 45 \mathrm{~s} \text {, ext. at } 65^{\circ} \mathrm{C}, 4 \mathrm{mins}\end{array}$ & $\begin{array}{l}\text { (Olobatoke and Mulugeta, } \\
\text { 2015) }\end{array}$ \\
\hline $\begin{array}{l}\text { cat } \\
\text { cat }\end{array}$ & $\begin{array}{l}\text { F: TCCCAATGGCATCGTAAAGAAC } \\
\text { R: TCGTGGTATTCACTCGAGAGCG }\end{array}$ & 310 & $\begin{array}{l}95^{\circ} \mathrm{C}, 5 \text { mins; } 35 \text { cyc. of } 94^{\circ} \mathrm{C}, 30 \mathrm{~S}, 55^{\circ} \mathrm{C} \text {, } \\
30 \mathrm{~S}, 72^{\circ} \mathrm{C}, 30 \mathrm{~s} \text {, ext. at } 72^{\circ} \mathrm{C}, 10 \mathrm{mins}\end{array}$ & $\begin{array}{l}\text { (Olobatoke and Mulugeta, } \\
\text { 2015) }\end{array}$ \\
\hline $\begin{array}{l}\operatorname{aad} A \\
\operatorname{aad} A\end{array}$ & $\begin{array}{l}\text { F: ATCCTTCGGCGCGATTTTG } \\
\text { R: GCAGCGCAATGACATTCTTG }\end{array}$ & 282 & $\begin{array}{l}94{ }^{\circ} \mathrm{C}, 3 \text { mins; } 30 \mathrm{cyc}, 94^{\circ} \mathrm{C} 30 \mathrm{~s}, 62^{\circ} \mathrm{C} 30 \\
\mathrm{~s}, 72{ }^{\circ} \mathrm{C} 1 \text { mins, ext at } 72{ }^{\circ} \mathrm{C}, 7 \mathrm{mins}\end{array}$ & (Aarestrup et al., 2003) \\
\hline $\begin{array}{l}q n r A \\
q n r A\end{array}$ & $\begin{array}{l}\text { F: TCAGCAAGAGGATTTCTCA } \\
\text { R: GGCAGCACTATGACTCCCA }\end{array}$ & 627 & $\begin{array}{l}95^{\circ} \mathrm{C}, 5 \mathrm{mins}, 30 \mathrm{cyc}, 94 \mathrm{C} 40 \mathrm{~s}, 50^{\circ} \mathrm{C} 60 \mathrm{~s} \text {, } \\
72^{\circ} \mathrm{C} 90 \mathrm{~s} \text {, ext at } 72 \mathrm{C}, 10 \mathrm{mins}\end{array}$ & (Akiyama and Khan, 2011) \\
\hline $\begin{array}{l}\text { intI1 } \\
\text { intI1 }\end{array}$ & $\begin{array}{l}\text { F: ACATGTGATGGCGACGCACGA } \\
\text { R: ATTTCTGTCCTGGCTGGCGA }\end{array}$ & 568 & $\begin{array}{l}95^{\circ} \mathrm{C} 3 \text { mins; } 30 \mathrm{cyc} \text {, at } 95^{\circ} \mathrm{C} 30 \mathrm{~s}, 55^{\circ} \mathrm{C} \\
30 \mathrm{~s}, 72^{\circ} \mathrm{C} 30 \mathrm{~s} ; \text { ext } 72^{\circ} \mathrm{C} \text { for } 10 \mathrm{mins}\end{array}$ & (Tankson et al., 2005) \\
\hline
\end{tabular}

\section{RESULTS}

\section{Identification of Salmonella spp.}

The Salmonella serovars detected from rats included $S$. typhimurium ( $\mathrm{n}=26,38.2 \%), S$. enteritidis $(\mathrm{n}=12,17.6 \%), S$. newport (n=8, 11.8\%), S. heidelberg ( $\mathrm{n}=7,10.3 \%)$, S. bongori $(\mathrm{n}=6,8.8 \%)$, S. enterica serovar Paratyphi B $(\mathrm{n}=4,5.9 \%)$, $S$. tennessee $(\mathrm{n}=3,4.4 \%)$ and $S$. pullorum $(\mathrm{n}=2,2.9 \%)$. The predominant Salmonella serovars isolated from chickens were $S$. typhimurium $(\mathrm{n}=18,39.1 \%), S$. heidelberg $(\mathrm{n}=9,19.6 \%), S$. bongori $(\mathrm{n}=7,15.2 \%)$, S. enteritidis $(\mathrm{n}=6,13.0 \%), S$. paratyphi B $(\mathrm{n}=3,6.5 \%)$ and $S$. newport $(\mathrm{n}=3,6.5 \%)$.

\section{Phenotypic antimicrobial resistance of Salmonella species}

The Salmonella isolates revealed resistance to rifampicin $(n=114,100 \%)$, tetracycline $(n=78,68 \%)$, ciprofloxacin $(n=55,48 \%)$, sulphonamides $(n=48,42 \%)$, cephalothin $(n=20,18 \%)$, chloramphenicol $(n=45,39 \%)$, streptomycin $(n=20$, $18 \%)$, enrofloxacin $(n=6,5 \%)$, ampicillin $(n=32,28 \%)$, amoxicillin/clavulanic acid $(n=7,6 \%)$ and nalidixic acid 38 (33\%), and gentamicin $5(4 \%)$. All Salmonella isolated from rat were susceptible to gentamicin as shown in table 2.

Five $S$. typhimurium were MDR for up to six different antibiotics (rifampicin, tetracycline, enrofloxacin, cephalothin, ciprofloxacin, and sulphonamides). Some isolates like $S$. enteritidis and $S$. typhimurium exhibited resistance for up to five antibiotics (rifampicin, tetracycline, enrofloxacin, cephalothin, and ciprofloxacin) and one $S$. enteritidis for five (rifampicin, enrofloxacin, cephalothin, ciprofloxacin, and streptomycin). Furthermore, different isolates exhibited resistance for three to four antibiotics as listed in table 3.

\section{Genotypic antimicrobial resistance of Salmonella isolates}

The results of the analysis of Salmonella isolates for the occurrence of ARGs are shown in table 4. Seventy-eight (68\%) isolates encoding class 1 integrons were detected from Salmonella spp. and most of the isolates which were harboring different resistance genes were also carrying class 1 integrons. In addition, the majority of the isolates which were harboring class 1 integrons were from the rats $(n=52)$ while 26 isolates were from the chickens. Different resistance gene patterns were indicated by $S$. typhimurium, $S$. enteritidis, $S$. heidelberg, $S$. bongori, $S$. newport, $S$. enterica serovar Paratyphi B, $S$. tennessee and $S$. pullorum; respectively. The mentioned results are shown in table 5. 
Table 2. Antimicrobial resistance of Salmonella serovars isolated from rats (Rattus spp.) and layer chickens in poultry houses, North West, South Africa

\begin{tabular}{lccccc}
\hline Antibiotic & Abbreviation & $\begin{array}{c}\text { Breakpoint disc } \\
(\boldsymbol{\mu g})\end{array}$ & Chickens (n=46) & Rats (n=68) & Total (n=114) \\
\hline Ampicillin & AMP & $(10 \mu \mathrm{g})$ & $29(63 \%)$ & $3(4 \%)$ & $32(28 \%)$ \\
Sulphonamides & SSS & $(300 \mu \mathrm{g})$ & $36(78 \%)$ & $12(18 \%)$ & $48(42 \%)$ \\
Cephalothin & KF & $(30 \mu \mathrm{g})$ & $8(17 \%)$ & $12(18 \%)$ & $20(18 \%)$ \\
Tetracycline & TE & $(30 \mu \mathrm{g})$ & $46(100 \%)$ & $32(47 \%)$ & $78(68 \%)$ \\
Ciprofloxacin & CIP & $(30 \mu \mathrm{g})$ & $34(74 \%)$ & $21(31 \%)$ & $55(48 \%)$ \\
Nalidixic acid & NA & $(30 \mu \mathrm{g})$ & $37(80 \%)$ & $1(2 \%)$ & $38(33 \%)$ \\
Chloramphenicol & CA & $(10 \mu \mathrm{g})$ & $36(78 \%)$ & $9(13 \%)$ & $45(39 \%)$ \\
Gentamicin & GM & $(5 \mu \mathrm{g})$ & $5(11 \%)$ & $0(0 \%)$ & $5(4 \%)$ \\
Enrofloxacin & ENR & $(5 \mu \mathrm{g})$ & $0(0.0 \%)$ & $6(9 \%)$ & $6(5 \%)$ \\
Rifampicin & RIF & $(10 \mu \mathrm{g})$ & $46(100 \%)$ & $68(100 \%)$ & $114(100 \%)$ \\
Streptomycin & STR & $(5 \mu \mathrm{g})$ & $12(25 \%)$ & $8(12 \%)$ & $20(18 \%)$ \\
Amoxicillin/clavulanic Acid & AMC & $(30 \mu \mathrm{g})$ & $5(11 \%)$ & $2(3 \%)$ & $7(6 \%)$ \\
\hline
\end{tabular}

Table 3. Antimicrobial resistance and the prevalence of resistant strains in Salmonella isolates from rats (Rattus spp.) and layer chickens in poultry houses, North West, South Africa

\begin{tabular}{|c|c|c|c|c|c|c|c|c|}
\hline $\begin{array}{ll}\text { MAR Phenotypes } & \text { Isolates } \\
\end{array}$ & $\begin{array}{c}S . \\
\text { typhimurium }\end{array}$ & $\begin{array}{c}S . \\
\text { enteritidis }\end{array}$ & $\begin{array}{c}S . \\
\text { newport }\end{array}$ & $\begin{array}{c}S . \\
\text { heidelberg }\end{array}$ & $\begin{array}{c}S . \\
\text { bongori }\end{array}$ & $\begin{array}{l}\text { S. enterica } \\
\text { paratyphi } B\end{array}$ & $\begin{array}{c}S . \\
\text { pullorum }\end{array}$ & $\begin{array}{c}S . \\
\text { tennessee }\end{array}$ \\
\hline ENR, TE, GM, KF, STR, SSS & 5 & - & - & - & - & - & - & - \\
\hline ENR, TE, GM, KF, STR & 1 & 3 & - & - & - & - & - & - \\
\hline ENR, GM, KF, STR, RIF & 1 & 1 & - & 1 & - & - & - & - \\
\hline ENR, NA, TE, KF, STR & - & 1 & - & - & 1 & - & - & - \\
\hline ENR, AMP, SSS, NA & 1 & - & - & - & - & - & - & - \\
\hline ENR, AMP, TE, SSS & 1 & - & - & - & - & - & - & - \\
\hline ENR, NA, TE, STR & - & - & 1 & - & - & - & - & 1 \\
\hline ENR, NA, TE, SSS & 1 & - & - & - & 2 & - & - & - \\
\hline ENR, TE, GM, KF & 3 & - & - & - & - & - & - & - \\
\hline ENR, CA, TE, GM & - & - & - & - & 1 & - & - & - \\
\hline ENR, TE, STR, SSS & - & 1 & - & - & & - & 1 & - \\
\hline ENR, AMP, KF, SSS & - & - & 1 & - & - & - & - & - \\
\hline ENR, TET, KF & - & - & - & 1 & - & - & - & - \\
\hline ENR, NA, SSS & - & - & - & 1 & - & - & 1 & - \\
\hline ENR, AMP, STR & 1 & - & 1 & - & - & - & - & - \\
\hline ENR, NA, RIF & - & 1 & - & - & - & 1 & - & - \\
\hline ENR, TE, RIF & - & - & - & - & - & - & - & 1 \\
\hline
\end{tabular}

Table 4. Antibiotic resistance genes among the different Salmonella spp. isolated from rats (Rattus spp). and layer chickens in poultry houses around North West, South Africa.

\begin{tabular}{lccccc}
\hline Antimicrobial agent & $\begin{array}{c}\text { Class of } \\
\text { antimicrobials }\end{array}$ & $\begin{array}{c}\text { Genes } \\
\text { tested }\end{array}$ & $\begin{array}{c}\text { No. of } \\
\text { isolates }\end{array}$ & $\begin{array}{c}\text { Resistant } \\
\text { phenotype (\%) }\end{array}$ & $\begin{array}{c}\text { Resistance genes and } \\
\text { integrons (\%) }\end{array}$ \\
\hline Chloramphenicol & Phenicol & cat & 114 & $45(39 \%)$ & $11(10 \%)$ \\
\hline Tetracycline & Tetracycline & tet & 114 & $78(68 \%)$ & $21(18 \%)$ \\
\hline Ampicillin & Beta-lactam & blaTEM & 114 & $32(28 \%)$ & $4(4 \%)$ \\
\hline Sulfonamide & Sulfonamide & Sul & 114 & $48(42 \%)$ & $16(14 \%)$ \\
\hline Streptomycin & Aminoglycoside & aadA & 114 & $20(18 \%)$ & $6(5 \%)$ \\
\hline Ciprofloxacin & Quinolones & qnr-A & 114 & $55(48 \%)$ & $20(18 \%)$ \\
\hline Class 1 integrons & - & intII & 114 & - & $78(68 \%)$ \\
\hline Nit & & &
\end{tabular}


Table 5. The number of Salmonella isolates containing antimicrobial resistance genes and class 1 integrons recovered from rats (Rattus spp.) and layer chickens in poultry houses around North West, South Africa.

\begin{tabular}{lcccccccc}
\hline Genotype & $\begin{array}{c}S . \\
\text { typhimurium }\end{array}$ & $\begin{array}{c}S . \\
\text { enteritidis }\end{array}$ & $\begin{array}{c}S . \\
\text { newport }\end{array}$ & $\begin{array}{c}S . \\
\text { heidelberg }\end{array}$ & $\begin{array}{c}S . \\
\text { bongori }\end{array}$ & $\begin{array}{c}\text { S. enterica } \\
\text { paratyphi B }\end{array}$ & $\begin{array}{c}S . \\
\text { pullorum }\end{array}$ & $\begin{array}{c}S . \\
\text { tennessee }\end{array}$ \\
\hline cat & 17 & 6 & 6 & 7 & 7 & 2 & 1 & 2 \\
\hline tet & 25 & 7 & 5 & 9 & 7 & 2 & - & - \\
\hline blaTEM & 17 & 7 & - & 1 & 3 & 1 & - & - \\
\hline sul & 21 & 6 & - & 7 & 3 & 3 & - & - \\
\hline aadA & 1 & 1 & - & 5 & 2 & 1 & - & - \\
\hline qnrA & 13 & 8 & 1 & - & 1 & 2 & - & - \\
\hline intIl & 30 & 19 & 11 & 4 & 7 & 5 & 1 & 1 \\
\hline
\end{tabular}

aadA gene mediates bacterial resistance to streptomycin, blaTEM mediate bacterial resistance to ampicillin, cat gene mediates bacterial resistance to chloramphenicol, Sul3, Sul4 genes mediate bacterial resistance to sulfonamide, qnrA gene mediates bacterial resistance to quinolones, tet gene mediates bacterial resistance to tetracyclines, $n t I 1=$ Class 1 Integrons, S.: Salmonella.

\section{DISCUSSION}

This is the first study to demonstrate antimicrobial resistance in Salmonella spp. isolated from rats captured from chicken houses in North West province and to our knowledge in the whole of South Africa. The 12 antimicrobial drugs were tested in the present study, are commonly used for the treatment of bacterial infections of animals and human's health. Finding resistance to these commonly used antimicrobials is very significant because rats are never treated with antibiotics thus the antimicrobial resistance observed in Salmonella isolates from rats represents the contamination and circulation of resistant strains in the environment which ultimately affects both animals and humans.

The current study demonstrated a very high prevalence (100\%) resistance of Salmonella isolates to rifampicin using disc diffusion test. This result is consistent with previous studies conducted in Egypt (Mahmoud et al., 2018), in Sardinia, Italy (Piras et al., 2011), in Shandong, China (Zhao et al., 2017) and in the United Arab Emirates (Khan et al., 2010). Rifampicin is used as the first-line drug for the treatment of humans Tuberculosis (TB) in South Africa (McIntosh et al., 2018). In South Africa due to the presence of gold mines, a high number of people suffer from TB because of silica dust exposure (Phillips et al., 2014). Therefore, many people around the North West province, a province which has minings, are taking TB treatment (Chirehwa et al., 2018) and this may explain the high possibility that the drug is being discharged into the environment and as a result, environmental bacteria and rats are constantly exposed to the drug. Therefore, this finding is a significant concern for public health and further research is necessary to evaluate its effect on other bacterial species.

A high resistance rate of 78 isolates to tetracycline was observed on disc diffusion. However, when the same isolates were assessed using molecular methods targeting the tet gene, only 55 of the isolates were positive. Tetracycline is a low-cost medication in comparison to other antibiotics (Odoch et al., 2018) and therefore is extensively used for therapy and prophylaxis of animal and human infections (Ammons and Copié, 2013; Granados-Chinchilla and Rodríguez, 2017; Almaaytah et al., 2018). It is also commonly used at sub-therapeutic levels for growth promotion (Chopra and Roberts, 2001). This encourages selection for resistance and results in the presence of higher percentages of bacteria in the environment that cannot respond to treatment. Thus the high resistance finding did not surprising because previous studies have also reported that the most frequently detected ARG is tet gene (Zishiri et al., 2016).

Forty-eight (42\%) Salmonella isolates were resistant to sulphonamides on disc diffusion compared to 40 (35\%) of these isolates on molecular evaluation using the Sul gene. This result is not surprising because sulphonamides are a common antibiotic in chickens flocks (Bertelloni et al., 2017). Sulphonamides are used to treat some infectious diseases in chickens such as fowl typhoid, coccidiosis coryza and pullorum disease (Mehtabuddin et al., 2012) and thus are common in poultry houses. According to the results of a survey, 95.4\% of sulphonamides are used as water medication in South Africa (Eagar et al., 2012). Thus, this condition makes these drugs common environmental contaminants in water spills that can be picked up by all organisms of environment, consequently exert selective pressure on ARGs.

The results of the present study indicated 55 (48\%) of the Salmonella isolates were resistant to ciprofloxacin on disc diffusion. However, when these isolates were subjected to molecular evaluation of resistance using the qnr-A gene, $25(22 \%)$ out of 114 isolates were positive for the $q n r-A$ gene. Quinolones or fluoroquinolones have been used as a treatment option for salmonellosis for over 40 years (Balasundaram et al., 2017). Fluoroquinolones have actually been considered as one of the last options for the treatment of Salmonella spp. (Abdel-Maksoud et al., 2015). The absence of the $q n r-A$ gene in isolates that had a positive phenotype indicated that the disc diffusion method may either be more sensitive and causing a few false positive. To explain this contradiction it can also be noted that the target gene for ciprofloxacin is not always the qnrABSCD genes (Kim et al., 2016).

A total of $20(18 \%)$ isolates were found to be phenotypically resistant to streptomycin, of which half of these isolates were harboring aadA gene. This observation may be explained by a fact that this class can be encoded by different resistant genes. Chloramphenicol was used as the main treatment against Salmonella, since its discovery up to 1990 (Ishaleku et al., 2015). The increasing resistance of Salmonella spp. to chloramphenicol has previously been reported (Olobatoke and Mulugeta, 2015) from chicken samples in North West province, South Africa. The present evaluation isolated 45 (39\%) Salmonella specimens which were phenotypically resistant to chloramphenicol and 44 $(39 \%)$ of them were harboring cat gene. This suggests that there is an ongoing use of this antibiotic due to its broadspectrum activity, despite awareness of resistance. 
Only 32 (28\%) Salmonella isolates in this study were phenotypically resistant to ampicillin while in the molecular evaluation of the blaTEM gene, 29 (25\%) isolates were resistant. The absence of mentioned gene from some isolates that were phenotypically positive may indicate that the target gene for this antibiotic is not always the same or the disk diffusion test has high sensitivity and but not specificity to antibiotics resistance (Dickert et al., 1981). This finding causes more concerns because antibiotic resistance for ampicillin has previously been detected from poultry products around this area (Olobatoke and Mulugeta, 2015). A high number of the isolates showed MDR to tetracycline, ciprofloxacin, and sulphonamides, which are antimicrobial agents commonly used in veterinary medicine. This is worrying because some antibiotics are recommended drugs for the treatment of salmonellosis (Hirose et al., 2001). MDR Salmonella has been observed in other countries such as Malaysia (Thung et al., 2018). MDR Salmonella isolates are considered to be highly virulent than non-MDR (Thung et al., 2018) and this finding was a major concern in the current study.

In the present research, seventy-eight (68\%) Salmonella isolated from chickens and rats were harboring class 1 integrons and the majority of the isolates belonged to the rats $(\mathrm{n}=52)$. It was possible that these rats picked up Salmonella infections with resistance gene from the environment. Even though there were four classes of integrons associated with the resistance gene cassette, class 1 integrons had been more commonly observed than the other classes (Thong and Modarressi, 2011; Abatcha et al., 2018). According to literature, class 1 integrons are the most common integron types in MDR Salmonella spp. and plays a significant role in assisting the transfer of the resistance genes (Thong and Modarressi, 2011). The obtained results in the present study revealed that the Salmonella isolates had one or more genes that encode antibiotic resistance.

MDR genes were encountered from two Salmonella isolates harboring more than two resistance genes. Out of two the isolates, $S$. typhimurium was MDR regarding both disc diffusion test and gene resistance markers. MDR Salmonella isolates has been reported to cause illnesses in either humans and animals in different countries including; the USA and Denmark (Aarestrup et al., 2007), Italy (Graziani et al., 2008), Eastern China (Lu et al., 2014) and Vietnam (Vo et al., 2010). Moreover, the presence of MDR genes in isolated Salmonella spp. from rats must be taken seriously as these vertebrates can act as reservoirs and potentially can spread the bacteria to both human and animal surroundings.

\section{CONCLUSION}

The current research has pioneered antibiotic resistance investigation on Salmonella isolates from rats inhabiting chicken farms in North West, South Africa. The obtained results in the present study revealed that antibiotic resistance is well established in most of the Salmonella isolates infecting chickens and rats and the majority of isolates harbor more than two resistance genes. These findings provided a better understanding of the importance of rats in the transmission and maintenance of the antibiotic-resistant Salmonella spp. in poultry premises which can potentially be transferred to humans via chicken products.

\section{DECLARATIONS}

\section{Author's contributions}

Ramatla T. performed the experiments and wrote the first draft. Moeti OT and Thekisoe OMM provided the analysis tools and data analysis and reviewed the manuscript. Michelo S conceived and designed the experiments, provided reagents, materials and approved the final paper.

\section{Consent to publish} elsewhere.

All the authors agreed to publish the manuscript and declared that this work has not been previously published

\section{Competing interests}

The authors declare that they have no conflict of interest

\section{REFERENCES}

Aarestrup FM, Hendriksen RS, Lockett J, Gay K, Teates K, McDermott PF, White DG, Hasman H, Sørensen G and Bangtrakulnonth A (2007). International spread of multidrug-resistant Salmonella Schwarzengrund in food products. Emerging Infectious Diseases, 13: 726. DOI: https://doi.org/10.3201/eid1305.061489

Abatcha MG, Effarizah ME and Rusul G (2018). Prevalence, antimicrobial resistance, resistance genes and class 1 integrons of Salmonella serovars in leafy vegetables, chicken carcasses and related processing environments in Malaysian fresh food markets. Food Control, 91: 170-180. DOI: https://doi.org/10.1016/j.foodcont.2018.02.039

Abdel-Maksoud M, Abdel-Khalek R, El-Gendy A, Gamal RF, Abdelhady HM and House BL (2015). Genetic characterisation of multidrug-resistant Salmonella enterica serotypes isolated from poultry in Cairo, Egypt. African Journal of Laboratory Medicine 4: 1-7. DOI: https://doi.org/10.4102/aj1m.v4i1.158

Akiyama T and Khan AA (2011). Molecular characterization of strains of fluoroquinolone-resistant Salmonella enterica serovar Schwarzengrund carrying multidrug resistance isolated from imported foods. Journal of antimicrobial chemotherapy 67: 101-110. DOI https://doi.org/10.1093/jac/dkr414 
Almaaytah, A, Qaoud M, Khalil Mohammed G, Abualhaijaa A, Knappe D, Hoffmann R. and Al-Balas Q (2018). Antimicrobial and antibiofilm activity of UP-5, an ultrashort antimicrobial peptide designed using only arginine and biphenylalanine. Pharmaceuticals, 11:1-18. DOI: https://doi.org/10.3390/ph11010003

Ammons MC and Copié V (2013). Mini-review: lactoferrin: a bioinspired, anti-biofilm therapeutic. Biofouling, 29:443-455. DOI: https://doi.org/10.1080/08927014.2013.773317

Balasundaram P, Veerappapillai S and Karuppasamy R (2017). Quinolones and fluoroquinolones to treat Salmonella typhimurium: A review of metabolism and pharmacokinetics. Current Drug Metabolism, 18: 1085-1094. DOI: https://doi.org/10.2174/1389200218666170710185032

Bertelloni F, Tosi G, Massi P, Fiorentini L, Parigi M, Cerri D and Ebani VV (2017). Some pathogenic characters of paratyphoid Salmonella enterica strains isolated from poultry. Asian Pacific Journal of Tropical Medicine, 10: 1161-1166. DOI: https://doi.org/10.1016/j.apjtm.2017.10.023

Chirehwa M, Wiesner L, Wright B, Smythe W, Kramer N and McIlleron H (2018). Quality assurance of rifampicincontaining fixed-drug combinations in South Africa: dosing implications. The International Journal of Tuberculosis and Lung Disease, 22: 537-543. DOI: https://doi.org/10.5588/ijtld.17.0697

Choi CO (2007). Pollution in solution-Drug-resistance DNA as the latest freshwater threat. Scientific American, 296 (1): $22-23$

Chopra I and Roberts M (2001). Tetracycline antibiotics: mode of action, applications, molecular biology, and epidemiology of bacterial resistance. Microbiology and Molecular Biology Reviews, 65: 232-260. DOI: https://doi.org/10.1128/MMBR.65.2.232-260.2001

Dickert H, Machka K and Braveny I (1981). The uses and limitations of disc diffusion in the antibiotic sensitivity testing of bacteria. Infection, 9: 18-24. DOI: https://doi.org/10.1007/BF01640803

Eagar H, Swan G and Van Vuuren M (2012). A survey of antimicrobial usage in animals in South Africa with specific reference to food animals. Journal of the South African Veterinary Association, 83: 15-23. DOI: https://doi.org/10.4102/jsava.v83i1.16

Frye JG and Jackson CR (2013). Genetic mechanisms of antimicrobial resistance identified in Salmonella enterica, Escherichia coli, and Enteroccocus spp. isolated from US food animals. Frontiers in Microbiology, 4: 135. DOI: https://doi.org/10.3389/fmicb.2013.00135

Granados-Chinchilla F and Rodríguez C (2017). Tetracyclines in food and feedingstuffs: From regulation to analytical methods, bacterial resistance, and environmental and health implications. Journal of Analytical Methods in Chemistry, 2017: 135. DOI: https://doi.org/10.1155/2017/1315497

Graziani C, Busani L, Dionisi A, Lucarelli C, Owczarek S, Ricci A, Mancin M, Caprioli A and Luzzi I (2008). Antimicrobial resistance in Salmonella enterica serovar Typhimurium from human and animal sources in Italy. Veterinary Microbiology, 128: 414-418. DOI: https://doi.org/10.1016/j.vetmic.2007.10.017

Hirose K, Tamura K, Sagara H and Watanabe H (2001). Antibiotic Susceptibilities of Salmonella enterica serovar Typhi and S. enterica Serovar Paratyphi A Isolated from Patients in Japan. Antimicrobial Agents and Chemotherapy, 45: 956-958. DOI: https://doi.org/10.1128/AAC.45.3.956-958.2001

Hong YP, Wang YW, Huang IH, Liao YC, Ku HC, Liu YY, Tu YH, Chen BH, Liao YS and Chiou CS (2018). Genetic relationships among multidrug-resistant Salmonella enterica serovar Typhimurium strains from Humans and Animals. Antimicrobial Agents and Chemotherapy. 00213-00218. DOI: https://doi.org/10.1128/AAC.00213-18

Ishaleku D, Umeh E, Amali O and Gberikon G (2015). The Reemergence of Chloramphenicol Sensitive Salmonella species among Typhoid Fever Patients in the Southern Geographical Zone of Nasarawa State, Nigeria. Journal of Infectious Disease and Therapy, 3: 1-3. DOI: http://dx.doi.org/10.4172/2332-0877.1000219

Khan M, Suryanarayan P, Ahmed MM, Vaswani RB, Faheem SM (2010). Antimicrobial susceptibility of Salmonella isolates from chicken meat samples in Dubai, United Arab Emirates. International Journal of Food, Nutrition and Public Health, 3: 149-159. DOI: http://eprints.manipal.edu/id/eprint/142216

Kim J, Han X, Bae J, Chui L, Louie M., Finley R, Mulvey MR, Ferrato CJ. and Jeon B (2016). Prevalence of plasmidmediated quinolone resistance (PMQR) genes in non-typhoidal Salmonella strains with resistance and reduced susceptibility to fluoroquinolones from human clinical cases in Alberta, Canada, 2009-13. Journal of Antimicrobial Chemotherapy, 10: 2988-2990. DOI: https://doi.org/10.1093/jac/dkw232

Lu Y, Zhao H, Sun J, Liu Y, Zhou X, Beier RC, Wu G and Hou X (2014). Characterization of multidrug-resistant Salmonella enterica serovars Indiana and Enteritidis from chickens in Eastern China. PLoS One, 9: e96050. DOI: https://doi.org/10.1371/journal.pone.0096050

Magiorakos AP, Srinivasan A, Carey R, Carmeli Y, Falagas M, Giske C, Harbarth S, Hindler J, Kahlmeter G and Olsson- Liljequist B (2012). Multidrug- resistant, extensively drug- resistant and pandrug- resistant bacteria: an international expert proposal for interim standard definitions for acquired resistance. Clinical Microbiology and Infection, 18: 268-281. DOI: https://doi.org/10.1111/j.1469-0691.2011.03570.x

Mahmoud M, Askora A, Barakat AB, Rabie OEF and Hassan SE (2018). Isolation and characterization of polyvalent bacteriophages infecting multi drug resistant Salmonella serovars isolated from broilers in Egypt. International Journal of Food Microbiology, 266: 8-13. DOI: https://doi.org/10.1016/j.ijfoodmicro.2017.11.009 
Mathole M, Muchadeyi F, Mdladla K, Malatji D, Dzomba E and Madoroba E (2017). Presence, distribution, serotypes and antimicrobial resistance profiles of Salmonella among pigs, chickens and goats in South Africa. Food Control, 72: 219-224. DOI: https://doi.org/10.1016/j.foodcont.2016.05.006

McIntosh AI, Jenkins HE, White LF, Barnard M, Thomson DR, Dolby T, Simpson J, Streicher EM, Kleinman MB and Ragan EJ (2018). Using routinely collected laboratory data to identify high rifampicin-resistant tuberculosis burden communities in the Western Cape Province, South Africa: A retrospective spatiotemporal analysis. PLoS Medicine, 15: e1002638. DOI: https://doi.org/10.1371/journal.pmed.1002638

Mehtabuddin A, Ahmad T, Nadeem S, Tanveer Z and Arshad J (2012). Sulfonamide residues determination in commercial poultry meat and eggs. Journal of Animal and Plant Sciences, 22: 473-478.

Odoch T, Sekse C, L’Abee-Lund TM, Høgberg Hansen HC, Kankya C and Wasteson Y (2018). Diversity and Antimicrobial resistance genotypes in Non-typhoidal Salmonella isolates from poultry farms in Uganda. International Journal of Environmental Research and Public Health, 15: 324. DOI: https://doi.org/10.3390/ijerph15020324

Olobatoke RY and Mulugeta SD (2015). Incidence of non-typhoidal Salmonella in poultry products in the North West Province, South Africa. South African Journal of Science, 111: 1-7. DOI: https://doi.org/10.17159/sajs.2015/20140233

Özgen, C (2007). Isolation, molecular characterization of food-borne drug resistant Salmonella spp. and detection of class 1 integrons (Doctoral dissertation, Middle East Technical University).

Phillips J, Vorajee N, Davies J, Nelson G, Murray J and Ndlovu N (2014). Marikana autopsies highlight occupational diseases amongst platinum mine workers. Occupational Health Southern Africa, 20: 6-12. DOI: https://hdl.handle.net/10520/EJC156787

Piras F, Brown DJ, Meloni D, Mureddu A and Mazzette R (2011). Investigation of Salmonella enterica in Sardinian slaughter pigs: prevalence, serotype and genotype characterization. International Journal of Food Microbiology, 151: 201-209. DOI: https://doi.org/10.1016/j.ijfoodmicro.2011.08.025

Raissy M and Ansari M (2011). Antibiotic susceptibility of Lactococcus garvieae isolated from rainbow trout (Oncorhynchus mykiss) in Iran fish farms. African Journal of Biotechnology, 10: 1473-1476. DOI: https://doi.org/ 10.5897/AJB10.523

Schroeder M, Brooks BD and Brooks AE (2017). The complex relationship between virulence and antibiotic resistance. Genes, 8: 39. DOI: https://doi.org/10.3390/genes8010039

Tankson JD, Fedorka-Cray PJ, Jackson CR and Headrick M (2005). Genetic relatedness of a rarely isolated Salmonella: Salmonella enterica serotype Niakhar from NARMS animal isolates. Journal of antimicrobial chemotherapy 57: 190-198. DOI: https://doi.org/10.1093/jac/dki439

Thong KL and Modarressi S (2011). Antimicrobial resistant genes associated with Salmonella from retail meats and street foods. Food Research International, 44: 2641-2646. DOI: https://doi.org/10.1016/j.foodres.2011.05.013

Thung TY, Radu S, Mahyudin NA, Rukayadi Y, Zakaria Z, Mazlan N, Tan BH, Lee E, Yeoh SL, Chin YZ and Tan CW (2018). Prevalence, virulence genes and antimicrobial resistance profiles of Salmonella serovars from retail beef in Selangor, Malaysia. Frontiers in Microbiology, 8: 2697. DOI: https://doi.org/10.3389/fmicb.2017.02697

Vo AT, Van Duijkeren E, Gaastra W and Fluit AC (2010). Antimicrobial resistance, class 1 integrons, and genomic island 1 in Salmonella isolates from Vietnam. PloS One, 5: e9440. DOI: https://doi.org/10.1371/journal.pone.0009440

Zhao X, Ye C, Chang W and Sun S (2017). Serotype distribution, antimicrobial resistance, and class 1 integrons profiles of Salmonella from animals in slaughterhouses in Shandong province, China. Frontiers in Microbiology, 8: 1049. DOI: https://doi.org/10.3389/fmicb.2017.01049

Zishiri OT, Mkhize N and Mukaratirwa S (2016). Prevalence of virulence and antimicrobial resistance genes in Salmonella spp. isolated from commercial chickens and human clinical isolates from South Africa and Brazil. Onderstepoort Journal of Veterinary Research, 83: 1-11. DOI: https://doi.org/10.4102/ojvr.v83i1.1067 